\title{
Influence of magnetic iron oxide nanoparticles on red blood cells and Caco- 2 cells
}

\author{
Daniel Moersdorf ${ }^{1}$, Pierre Hugounenq ${ }^{1}$, Lai Truonc Phuoc ${ }^{2}$, Hind Mamlouk-Chaouachi ${ }^{2}$, \\ Delphine Felder-Flesch ${ }^{2}$, Sylvie Begin-Colin ${ }^{2}$, Geneviève Pourroy ${ }^{2}$, Ingolf Bernhardt ${ }^{1}$
}

\footnotetext{
${ }^{1}$ Laboratory of Biophysics, Saarland University, Campus, Building A2.4, 66123 Saarbruecken, Germany;

${ }^{2}$ Institut de Physique et Chimie des Matériaux de Strasbourg, UMR 7504 CNRS-Université de Strasbourg-ECPM, 23 rue du Loess, 67034 Strasbourg Cedex 2, France.

Email: i.bernhardt@mx.uni-saarland.de
}

Received 14 September 2010; revised 22 October 2010; accepted 26 October 2010.

\begin{abstract}
The interactions of two types of cells (red blood cells, Caco-2 cells) with magnetic iron oxide nanoparticles (non-grafted, citrate-grafted, dendrimer-grafted) of $11 \mathrm{~nm}$ in size have been investigated. We focused on two important physiological parameters of the cells, the intracellular $\mathrm{pH}$ and the intracellular $\mathrm{Ca}^{2+}$ content. The results show that the nanoparticles do not have a significant influence on the $\mathrm{pH}$ and $\mathrm{Ca}^{2+}$ content of Caco-2 cells. The $\mathrm{Ca}^{2+}$ content of red blood cells is also not affected but the intracellular $\mathrm{pH}$ is slightly reduced.
\end{abstract}

Keywords: Red Blood Cells; Caco-2 Cells; $\mathrm{Ca}^{2+}$ Content; Intracellular PH; Magnetic Iron Oxide Nanoparticles

\section{INTRODUCTION}

One of the main topics in biotechnology relies on the development of various systems, ranging in the nanoand submicronic scales for diagnostics, imaging, drug delivery, or cancer therapy [1,2]. These systems comprise association between organic self-assembled vehicles (vesicles, emulsions, microbubbles, dendrimers) and inorganic nanoparticles. Designing and synthesizing hybrid materials combining at least two of these components are of the utmost importance since such materials can ensure a strong versatility and adaptability. This is the aim of project in which this study has been achieved [Nanomagdye FP7 EU Project grant agreement nr NMP3-SL-2008-214032]. However, before combining each component, the toxicity towards cells has to be studied.

In our studies, magnetic iron oxide nanoparticles noncoated or coated with citrate or dendrons have been tested on cells. We first investigate the effect on physiological parameters of RBCs. As fundamental physiological parameters, the intracellular $\mathrm{Ca}^{2+}$ content as well as the intracellular $\mathrm{pH}\left(\mathrm{pH}_{\mathrm{i}}\right)$ have been chosen. These parameters can be measured using fluorescent dyes. For comparison and as an example of cancer cells, which are targets for nanoparticles in medical treatment, Caco-2 cells have been chosen. It should be mentioned that RBCs and Caco-2 cells differ in one main fundamental aspect - no endocytosis occurs in RBCs whereas Caco-2 cells have such a mechanism [3].

Many publications report experiments on the interaction of targeted tissues or cells and nanoparticles. However, it is sometimes unclear whether these particles show unspecific reactions with other tissues or cells they come in contact with [4]. For example, nanoparticles injected into the blood stream and therefore, coming in contact with red blood cells (RBCs), could adhere to the surface of the cells (and in this case not move to the target cells) or even enter the cells. Such an uptake of nanoparticles by RBCs has been reported by Geiser $e t$ al. [5] and Rothen-Rutishauser et al. [6]. In addition, in both cases nanoparticles could affect physiological parameters of the cells. For instance, it has been reported that iron oxide nanoparticles can increase the membrane permeability of human microvascular endothelial cells [7].

\section{MATERIAL AND METHODS}

The influence of bare iron oxide nanoparticles $(11 \mathrm{~nm}$ diameter) and decorated with an organic shell (citrate or dendrimer) on the intracellular $\mathrm{pH}\left(\mathrm{pH}_{\mathrm{i}}\right)$ and the intracellular $\mathrm{Ca}^{2+}$ content of RBCs and Caco-2 cells has been investigated.

\subsection{Nanoparticles}

The bare, citrated or dendronized nanoparticles used were 
synthesized at IPCMS, Strasbourg. The non grafted iron oxide nanoparticles were prepared according to the method of Daou et al. [8] by coprecipitation at $70^{\circ} \mathrm{C}$ from ferrous $\mathrm{Fe}^{2+}$ and ferric $\mathrm{Fe}^{3+}$ ions and a $\left(\mathrm{N}\left(\mathrm{CH}_{3}\right)_{4} \mathrm{OH}\right)$ solution. The nanoparticles were characterized by X-ray diffraction (XRD), magnetic measurements and microscopy techniques. They exhibit the magnetite spinel structure and a lattice parameter of $0.8379 \pm 0.0004 \mathrm{~nm}$ corresponding to an intermediate phase between maghemite and magnetite written $\mathrm{Fe}_{3-\mathrm{x}} \mathrm{O}_{4}$. They are $11 \pm 2 \mathrm{~nm}$ in size deduced from TEM measurements and XRD characterizations. A generation zero dendritic molecule $\left(\mathrm{C}_{41} \mathrm{H}_{77} \mathrm{O}_{22} \mathrm{P}, 953.02 \mathrm{~g} / \mathrm{mol}\right)$ was grafted at their surface by mean of a phosphonate coupling agent following the method described by Daou et al. [9] and Basly et al. [10].

Citrate coated nanoparticles were obtained by introducing sodium citrate in a water suspension of nanoparticles and adjusting the $\mathrm{pH}$ at 4.0 with a buffer solution. Then the suspension was mechanically stirred for $24 \mathrm{~h}$, washed with water and centrifuged several times. Water is finally added in order to obtain a stable suspension of citrated nanoparticles.

\subsection{Preparation of RBCs}

The blood used for experiments was given by healthy human donors, stored at $4^{\circ} \mathrm{C}$ not longer than $24 \mathrm{~h}$, and washed three times by centrifugation at $2000 \mathrm{~g}$ for $5 \mathrm{~min}$ at room temperature in a physiological solution containing $145 \mathrm{mM} \mathrm{NaCl}, 7.5 \mathrm{mM} \mathrm{KCl}, 10 \mathrm{mM}$ glucose, 10 mM HEPES, pH 7.4.

\subsection{Preparation of CaCo-2 Cells}

The Caco- 2 cells were cultured in Dulbeccos modified Eagle medium. For detaching and separation the cells were trypsinated and washed three times by centrifugation at $2000 \mathrm{~g}$ for $5 \mathrm{~min}$ at room temperature in physiological solution.

\subsection{Loading with Fluorescent Dyes}

For intracellular $\mathrm{Ca}^{2+}$ and the intracellular $\mathrm{pH}$ measurements the fluorescent dye fluo-4 AM and BCECF AM were used, respectively. Stock solutions of the fluorescent dyes (1 mM) in Pluronic F-127 20\% in DMSO (Molecular Probes, USA)) were prepared. The dyes were added to the washed and re-suspended cells $(0.2 \% \mathrm{v} / \mathrm{v})$ at a concentration of $2 \mathrm{nM}$. After incubation for $30 \mathrm{~min}$ at $37^{\circ} \mathrm{C}$ the cells were washed three times (2000 g, $5 \mathrm{~min}$ ) to remove free dye in the medium surrounding the cells.

\subsection{Treatment of Cells with Nanoparticles}

The cells loaded with the dye (fluo-4 AM or BCECF AM) were incubated in a physiological solution containing 5 -
$50 \mu \mathrm{g} / \mathrm{ml}$ of nanoparticles for $30 \mathrm{~min}$ at $37^{\circ} \mathrm{C}$. The exposure time of $30 \mathrm{~min}$ has been selected to be able to measure changes of fast as well as slow processes of cellular reactions.

\subsection{Fluorescence Measurements}

After the 30 min incubation the cells were transferred on a cover slip and after 5 min (necessary time to let the cells settle down) the fluorescence intensity was measured with a fluorescence microscope (Eclipse TE2000-E, Nikon, Japan) for single cell investigations. Flow cytometry (FACScalibur, Becton Dickinson Bioscience, USA) measurements were carried out to investigate an higher amount of cells. In this case the cell suspension was immediately measured after the $30 \mathrm{~min}$ incubation.

\subsection{Calibration for $\mathbf{P H}_{\mathrm{i}}$ Determination}

A calibration curve of the fluorescence intensity depending on $\mathrm{pH}$ was created, using the $\mathrm{K}^{+} / \mathrm{H}^{+}$ionophore nigericin. For this reason $5 \mu \mathrm{M}$ nigericin was added to RBCs suspended in the calibration buffer solutions containing $135 \mathrm{mM} \mathrm{KCl,} 10 \mathrm{mM} \mathrm{NaCl}, 10 \mathrm{mM}$ glucose, 10 $\mathrm{mM}$ HEPES/NaOH $[11,12]$. The calibration curve was linear in the $\mathrm{pH}$ range 6.5-8.0.

\subsection{Reagents and Dyes}

The chemicals used were purchased from VWR (Germany) and Sigma Aldrich (USA). Fluorescent dyes from Molecular Probes (USA) were used for analysing the physiological parameters.

\subsection{Statistical Treatment of Results}

The data are presented as mean values \pm SD of independent experiments. The significance of differences was tested by paired or unpaired Student's t-test. Differences were considered significant if $p<0.05$. Each experiment was repeated at least 3 times on blood from different donors. For $\mathrm{Ca}^{2+}$ and $\mathrm{pH}_{\mathrm{i}}$ determinations using the fluorescence microscope at least 3 measurements (with blood from 3 different donors and at least 10 single cells from each blood, i.e. 30 single cells) were carried out for each experimental condition. For the FACS experiments 3 measurements (with blood from 3 different donors and 30.000 cells from each blood) were carried out and analysed under each experimental condition.

\section{RESULTS AND DISCUSSION}

The effect of non grafted, citrate grafted or dendronized nanoparticles on the intracellular $\mathrm{Ca}^{2+}$ content as well as on the $\mathrm{pH}_{\mathrm{i}}$ of $\mathrm{RBCs}$ and Caco-2 cells is shown in Figure 1. These two cellular parameters are largely independent from each other and play an important role for many relevant physiological processes. For example, they in- 
fluence the activity of cellular and membrane proteins, membrane ion transport as well as other membranebound processes (e.g., the interaction of the cytoskeleton with the cell membrane). In addition, changes in the $\mathrm{pH}_{\mathrm{i}}$ of RBCs are expected to happen in a relatively short time (some seconds), whereas changes in the intracellular $\mathrm{Ca}^{2+}$ content of RBCs are expected to occur in some

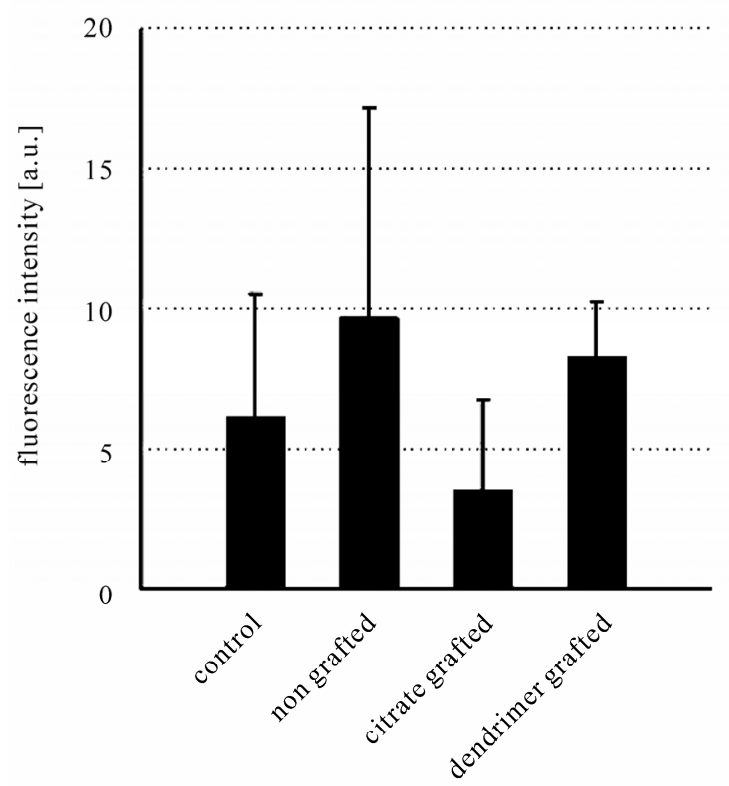

(a)

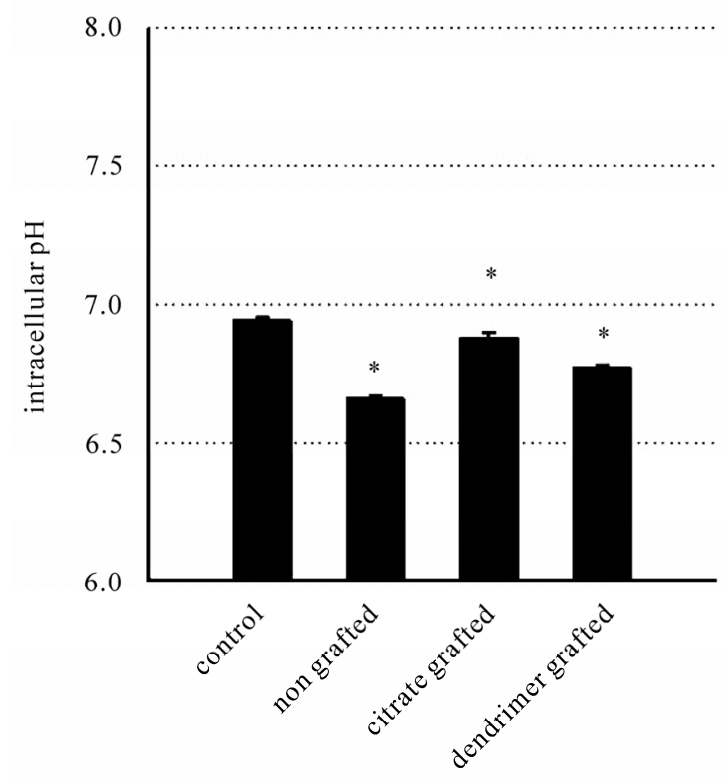

(c) minutes only $[13,14]$.

As one can see from Figures 1(a) and 1(b) there is no significant effect of any type of nanoparticles on the $\mathrm{Ca}^{2+}$ content of both cell types. However, it must be noted that the error bars (S.D.) are relatively high for RBCs (Figure 1(a)). The arbitrary units of the fluorescence intensity of single cells in the presence of the dif-

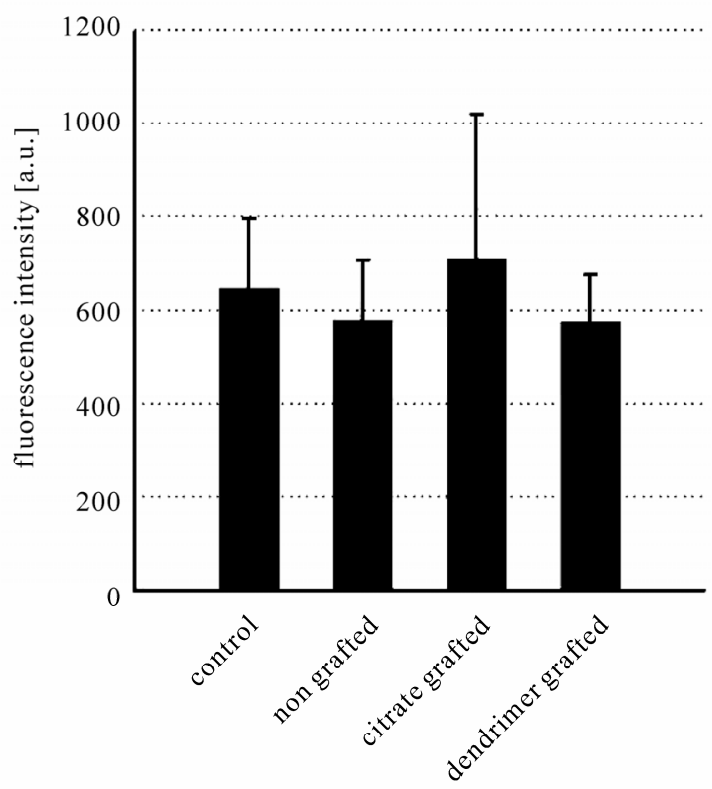

(b)

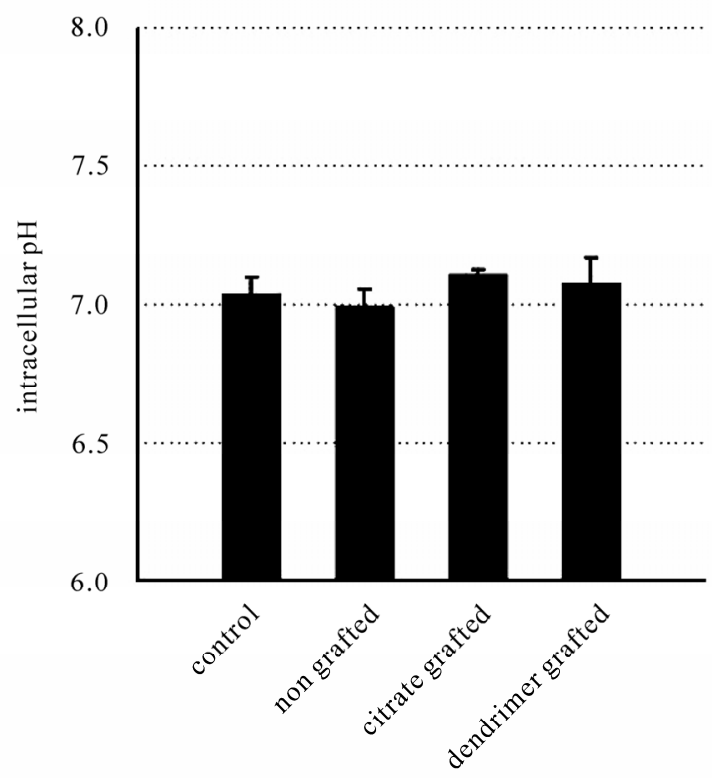

(d)

Figure 1. Fluorescence intensity of fluo-4 labelled RBCs (a) and Caco-2 cells (b) as well as intracellular pH (measured with BCECF) of RBCs (c) and Caco-2 cells (d). Measurements have been carried out with fluorescence microscope after $30 \mathrm{~min}$ of incubation of the cells with the nanoparticles. Each type of nanoparticles has been investigated with 10-20 cells of at least 3 different bloods. The results are shown as mean values \pm S.D. * indicate values which are statistical significant different from control $(p<0.01)$. 
ferent nanoparticles vary only between 0 and 20. The reason is that the intracellular $\mathrm{Ca}^{2+}$ content of these cells is very low and close to the detection minimum using fluo-4 as the $\mathrm{Ca}^{2+}$-sensitive fluorescent dye. It is well known that the intracellular $\mathrm{Ca}^{2+}$ content of RBCs is very low $[15,16]$ and it has been previously reported by our group that the ratiometric $\mathrm{Ca}^{2+}$-sensitive fluorescent dye fura-2 is not applicable for RBCs and that only fluo-4 is useful to monitor reasonable qualitative changes of the intracellular $\mathrm{Ca}^{2+}$ content (see [15] for more details).

To clarify the big variation of the fluorescence intensities of fluo-4, i.e. the $\mathrm{Ca}^{2+}$ content of the RBCs shown in Fig. 1a, comparable flow cytometry (FACS) investigations have been carried out. This method allows considering 30.000 cells in one single experiment, i.e. for one blood sample. Figure 2 shows a characteristic example of such flow cytometry measurement (one of three) for 2 types of nanoparticles in comparison to control. It can be clearly seen that the fluorescence peaks are identical, supporting the finding that there is no significant increase of the intracellular $\mathrm{Ca}^{2+}$ content when the RBCs are exposed to the nanoparticles. It should be mentioned that one big advantage of fluorescence microscopy is that single cells can be monitored over a certain time period. This allows seeing differences in cellular reactions and morphological changes and possible destructions of individual cells. In addition, some physiological parameters of RBCs are affected by shear forces $[17,18]$, which might be also the case during the process of cell flow through the capillary in a flow cytometer.

Figure 1(c) shows that the $\mathrm{pH}_{\mathrm{i}}$ of $\mathrm{RBCs}$ is slightly but significantly lowered after the cells are in contact with the different nanoparticles (compared to the control value). However, such effect in the range of 0.1 to 0.3 $\mathrm{pH}$ units seems not of fundamental physiological relevance. It has to be stated that the $\mathrm{pH}_{\mathrm{i}}$ value for the control is already about 0.1 to 0.2 units below the expected (literature) value [13]. The small effect of the nanoparticles on the $\mathrm{pH}_{\mathrm{i}}$ of $\mathrm{RBCs}$ could be due to the fact that RBCs can regulate their $\mathrm{pH}$ very efficiently and rapidly. Each RBC contains $10^{6}$ copies of a protein (band 3) responsible for the gas $\left(\mathrm{HCO}_{3}{ }^{-} / \mathrm{Cl}^{-}\right)$exchange and some other proteins for $\mathrm{pH}$ regulation like the $\mathrm{Na}^{+} / \mathrm{H}^{+}$exchanger $[14,19]$. The band 3 protein occupying a substantial area of the outer membrane surface [20] could be easily affected by the nanoparticles. Although $\mathrm{HCO}_{3}{ }^{-}$ was not explicitly added to the solutions, there is enough bicarbonate present (from the air-containing $\mathrm{CO}_{2}$ dissolving in the solutions) that the $\mathrm{HCO}_{3} / \mathrm{Cl}^{-}$exchanger is fully functioning. Furthermore, this exchanger also operates as a $\mathrm{Cl}^{-} / \mathrm{Cl}^{-}$exchanger and therefore normally no

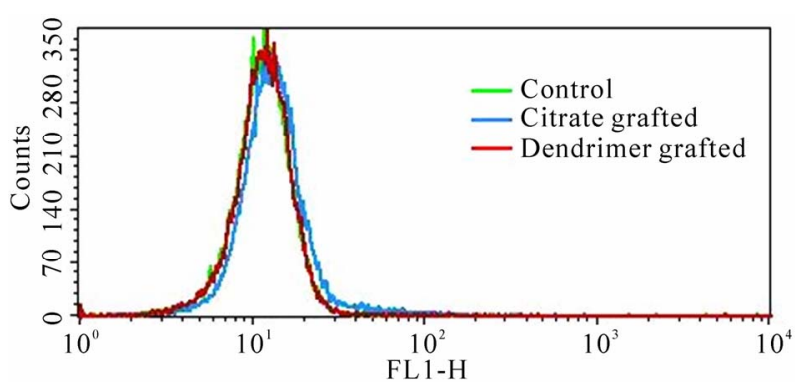

Figure 2. Fluorescence intensity of fluo-4 labelled RBCs. Measurements have been carried out with flow cytometry after 30 min of incubation of the cells without (control) and with nanoparicles (citrate grafted, dendromer grafted). For each measurement 30.000 cells were analysed. The figure shows one single experiment, representative for 3 different blood samples.

$\mathrm{HCO}_{3}{ }^{-}$has to be added when investigating $\mathrm{RBC}$ membrane transport [14].

Figure 1(d) shows that there is no significant effect of the various nanoparticles on $\mathrm{pH}_{\mathrm{i}}$ of Caco-2 cells.

In the described experiments investigating the effect of nanoparticles on RBCs (Figs. 1a and 1c) no haemolysis was observed. On the contrary, a haemolytic effect of magnetic nanoparticles (magnetite colloidal nanoparticles stabilised with citric acid) on animal RBCs was reported by Creanga et al. [21]. However, the authors mentioned that further investigations must be done to explain how nanoparticles can induce haemolysis of RBCs.

\section{CONCLUSION}

Nanoparticles can influence physiological parameters of cells. In our investigations we found a small but significant effect of nanoparticles on the intracellular $\mathrm{pH}\left(\mathrm{pH}_{\mathrm{i}}\right)$ of RBCs. The $\mathrm{pH}_{\mathrm{i}}$ of Caco-2 cells was not affected by the nanoparticles. The intracellular $\mathrm{Ca}^{2+}$ content of RBCs as well as Caco-2 cells did not significantly change when the cells were exposed to nanoparticles. Therefore, nanoparticles have to be tested not only with respect to their effect on target cells but also in respect of interactions with cells they can come in contact with, especially RBCs.

\section{ACKNOWLEDGEMENTS}

The research leading to these results has received funding from the European Community's Seventh Framework Programme (FP7 20072013) under grant agreement nr NMP3-SL-2008-214032.

\section{REFERENCES}

[1] Pankhurst, Q.A., Connolly, J., Jones, S.K. and Dobson, J. (2003) Applications of magnetic nanoparticles in biomedicine. J Phys D: Appl Phys, 36, R167-R181. 
[2] Park, K., Lee, S., Kang, E., Kim, K., Choi, K. and Kwon, I.C. (2009) New generation of multifunctional nanoparticles for cancer imaging and therapy. Adv Funct Mater, 19, 1553-1566.

[3] Win, K.Y. and Feng, S. (2005) Effects of particle size and surface coating on cellular uptake of polymeric nanoparticles for oral delivery of anticancer drugs. Biomaterials, 26, 2713-2722.

[4] Hillyer, J.F. and Albrecht, R.M. (2001) Gastrointestinal persorption and tissue distribution of differently sized colloidal gold nanoparticles. J Pharm Sci, 90, 1927-1936.

[5] Geiser, M., Rothen-Rutishauser, B., Kapp, N., Schürch, S., Kreyling, W., Schulz, H., Semmler, M., Im Hof, V., Heyder, J. and Gehr, P. (2005) Ultrafine particles cross cellular membranes by nonphagocytic mechanisms in lungs and in cultured cells. Environ Health Perspect, 113, 1555-1560.

[6] Rothen-Rutishauser, B., Schürch, S., Haenni, B., Kapp, N. and Gehr, P. (2006) Interaction of fine particles and nanoparticles with red blood cells visualized with advanced microscopic techniques. Environ Sci Technol, 40, 4353-4359.

[7] Apopa, P.L., Qian, Y., Shao, R., Guo, N.L., Schwegler-Berry, D., Pacurari, M., Porter, D., Xianglin, S., Vallyathan, V., Castranova, V. and Flynn, D.C. (2009) Iron oxide nanoparticles induce human microvascular endothelial cell permeability through reactive oxygen species production and microtubule remodelling. Part Fibre Toxicol, 6:1.

[8] Daou, T.J., Pourroy, G., Begin-Colin, S., Greneche, C. Ulhaq-Bouillet, J.M., Legare, P., Bernhardt, P., Leuvrey, C. and Rogez, G. (2006) Hydrothermal synthesis of monodisperse magnetite nanoparticles. Chem Mater, 18, 4399-4404.

[9] Daou, T.J., Pourroy, G., Greneche, J.M., Bertin, A., Felder-Flesch, D. and Begin-Colin, S. (2009) Water soluble dendronized iron oxide nanoparticles. Dalton Transactions, 23, 4442-4449.

[10] Basly, B., Felder-Flesch, D., Perriat, P., Billotey, C., Taleb, J., Pourroy, G. and Begin-Colin, S. (2010) Dendronized iron oxide nanoparticles as contrast agents for MRI. Chem Comm, 46, 985-987.

[11] Grinstein, S., Cohen, S. and Rothstein, A. (1984) Cyto- plasmic $\mathrm{pH}$ regulation in thymic lymphocytes by an amiloride-sensitive $\mathrm{Na}+\mathrm{H}+$ antiport. J Gen Physiol, 83, 341-369.

[12] Kummerow, D., Hamann, J., Browning, J.A., Wilkins, R., Ellory, J.C. and Bernhardt, I. (2000) Variations of intracellular $\mathrm{pH}$ in human erythrocytes via $\mathrm{K}+(\mathrm{Na}+) / \mathrm{H}+$ exchange under low ionic strength conditions. J Membr Biol, 176, 207-216.

[13] Bernhardt, I. and Weiss, E. (2003) Passive membrane permeability for ions and the membrane potential. In: Bernhardt, I. and Ellory, J.C., Eds., Red Cell Membrane Transport in Health and Disease, Springer-Verlag, Berlin, 83-109.

[14] Knauf, P.A. and Pal, P. (2003) Band 3 mediated transport. In: Bernhardt, I. and Ellory, J.C., Eds., Red Cell Membrane Transport in Health and Disease, Springer-Verlag, Berlin, 253-301.

[15] Kaestner, L., Tabellion, W., Weiss, E., Bernhardt, I. and Lipp, P. (2006) Calcium imaging of individual erythrocates: Problems and approaches. Cell Calcium, 39, 13-19.

[16] Bennekou, P. and Christophersen, P. (2003) Ion channels. In: Bernhardt, I. and Ellory, J.C., Eds., Red Cell Membrane Transport in Health and Disease, Springer-Verlag, Berlin, 139-152.

[17] Leveritt, L.B., Hellums, J.D., Alfrey, C.P. and Lynch, E. C. (1972) Red blood cell damage by shear stress. Biophys J, 12, 257-273.

[18] Wan, J., Ristenpart, W.D. and Stone, H.A. (2008) Dynamics of shear-induced ATP release from red blood cells. PNAS, 105, 16432-16437.

[19] Nikinmaa, M. (2003) Gas transport. In: Bernhardt, I. and Ellory, J.C., Eds., Red Cell Membrane Transport in Health and Disease, Springer-Verlag, Berlin, 489-509.

[20] Betz, T., Bakowsky, U., Mueller, M.R., Lehr, C.M. and Bernhardt, I. (2007) Conformational change of membrane proteins leads to shape changes of red blood cells. Bioelectrochemistry, 70, 122-126.

[21] Creanga, D.E., Culea, M., Nadejde, C., Oancea, S., Curecheriu, L. and Racuciu, M. (2009) Magnetic nanoparticle effects on the red blood cells. J Phys: Conf Ser, 170, 012019. 